\title{
4. Implications of ASEAN economic integration on services: a global computable general equilibrium analysis
}

\section{Kakali Mukhopadhyay*}

\section{INTRODUCTION}

The economies of the Association of Southeast Asian Nations (ASEAN) are aware of the key role services trade can play in development. And they have made services central to their integration agenda (ASEAN-World Bank 2015). At the 5th ASEAN Summit in Bangkok in 1995, ASEAN Economic Ministers (AEMs) signed the ASEAN Framework Agreement on Services (AFAS), which requires members to enhance market access and guarantee equal national treatment for service suppliers among ASEAN countries. Another landmark framework agreement related to services trade is the 2007 ASEAN Economic Community (AEC) Blueprint. ASEAN members agreed to subsequent rounds of AFAS negotiations and schedule liberalization commitments to 2015 - based on the parameters and timelines outlined in the AEC Blueprint. Detailed targets were set for integrating services markets, culminating in the free flow of services, investment and skilled labor by 2015 . AFAS would substantially eliminate restrictions on services trade among ASEAN countries to improve the efficiency and competitiveness of ASEAN services suppliers and to accelerate economic growth and job creation (ASEAN-World Bank 2015).

The commitments cover services such as air transport, business, construction, distribution, education, the environment, finance, healthcare, maritime transport, telecommunications and tourism. The AEMs also concluded eight mutual recognition arrangements (MRAs) for architects, medical and dental practitioners, and engineering, nursing and tourism professionals along with framework agreements for surveyors and accountants. The MRAs enable professional service providers certified 
or registered in their home country to be mutually recognized by other signatories (ASEAN-World Bank 2015).

The ASEAN Vision 2020 - of a single market and production base-is an essential step toward liberalizing services trade. Its success depends on how it is implemented and measured. Identifying barriers to services trade, the degree of liberalization and regulatory reforms must be examined and analyzed. As of 2016, ASEAN members generated $37 \%$ to $74 \%$ of gross domestic product (GDP) from services, far exceeding GDP from agriculture and industry. ${ }^{1}$ ASEAN services exports grew from $\$ 113.6$ billion in 2005 to $\$ 291.9$ billion in 2013 - a $12.5 \%$ average annual growth. Over the same period, services imports increased from $\$ 140.7$ billion to $\$ 298.6$ billion $(9.9 \%$ annual growth). In particular, liberalizing services trade requires policy reforms that attract investment and technology and create jobs for skilled labor (ASEAN-World Bank 2015).

On average, ASEAN services trade policies are more restricted than those of any other region in the world, except the Gulf States. The average Services Trade Restrictive Index (STRI) for the region is 60\% above the global average - although restrictions vary widely across ASEAN countries and across income levels. Cambodia and Singapore have the most open policies. Myanmar and Viet Nam are also relatively open with few restrictions, while services trade in Indonesia, Thailand, the Philippines, and Malaysia is tightly restricted.

Even with AFAS in place, ASEAN countries have not moved further. While there are some instances of markets opening up, there are also instances of new restrictions. For the six ASEAN members originally surveyed in 2008, there was little change in overall policy regime through 2012. Even with AFAS and some further liberalization, the goal of free flow of services remains a long way off (ASEAN-World Bank 2015).

There are two areas, however, where progress in services integration is clear. The first is in air transport, where some steps have been taken toward a regional open sky policy. The second is in the MRAs for skilled professionals. These suggest that regionalism could have incremental value when focusing on areas not addressed multilaterally — such as in professional services and transportation. ${ }^{2}$

Malaysia pioneered open, private higher education by fostering crossborder trade in educational services, implementing both the requisite regulatory framework and developing quality assurance infrastructure. Singapore strengthened its position as the regional financial hub by preparing an open domestic financial sector alongside its reformed regulatory framework. Thailand has been proactive in targeting high-value-added markets. While initially focusing on tourism, it has aggressively moved into healthcare through complementary policies such as compulsory public 
service for medical graduates and financial incentives for rural doctors. The Philippines has been successful in capturing a significant share of the global business process outsourcing market using a holistic approach. ${ }^{3}$

ASEAN has signed several services trade agreements with its " +3 " partners - the People's Republic of China (PRC), Japan, and the Republic of Korea. In October 2003, Japan and ASEAN signed a general free trade agreement (FTA) framework that led to a formal FTA coming into force on 1 December 2008. ASEAN and Japan continue to work within World Trade Organization (WTO) rules to progressively eliminate discriminatory measures on services trade, facilitate entry and temporary movement of business people, and enhance cooperation for greater efficiency and competitiveness.

ASEAN and the Republic of Korea signed and implemented the ASEAN-Korea Trade in Services Agreement (AKTIS) in 2009. In January 2007, the PRC and ASEAN signed an agreement on trade in services, effective July 2007.

The ASEAN-India Free Trade Agreement in Services and Investment was signed in September 2014 and came into force in July 2015. It covers telecommunications, information technology (IT), transportation and logistics, financial services, education, real estate, business services, health and social services, and the "Mode IV" free movement of semi-skilled labor and professionals. ${ }^{4}$ India and ASEAN set trade targets of $\$ 100$ billion by 2015 and $\$ 200$ billion by 2022 . In 2015 , however, total merchandise trade was just $\$ 58.7$ billion, down $13.29 \%$ from the $2014 \$ 67.7$ billion total. During the same period, foreign direct investments (FDI) from India leapt $164 \%$ - from $\$ 606$ million (2014) to $\$ 1.6$ billion (2015). ${ }^{5}$ In the other direction, ASEAN investments to India grew to $\$ 5.3$ billion in 2014/15. ${ }^{6}$ India holds a comparative advantage over the ASEAN nations in IT services, telecommunications, e-commerce, and engineering serviceswhereas ASEAN has the advantage in construction services, shipping and transportation, and logistics. Both are equally competitive in financial and insurance services (East Asia Forum 2013).

Using a global computable general equilibrium (CGE) framework, this chapter evaluates the effects ASEAN services trade liberalization would have in 2030 within ASEAN, between ASEAN and Japan, the Republic of Korea, the PRC, the +3 as a group, and between ASEAN and India. The Global Trade Analysis Project (GTAP) is primarily a tool for global trade analysis, and useful in studying the impact of service trade agreements. Results show that liberalizing services trade within ASEAN has a significant impact on output and trade. It finds that reducing tariffs to ASEAN's +3 partners significantly benefits ASEAN members. Moreover, it shows job creation in various service sectors across ASEAN, with the 
greatest impact in trade and transport - except in smaller ASEAN members, where employment growth is higher in agriculture and semi-skilled manufacturing.

Developing an effective cooperative regulatory framework is essential to promote both bilateral cooperation and ensure long-term benefits reach all ASEAN members (Vo and Bartlett 2006). Implementing the 15-yearold AFAS requires that efficient coordination between ASEAN working committees and specialized working groups must be accelerated. Working groups have been established for six sectors-business services, construction, maritime services, telecommunications, tourism, and healthcare. Air transportation, banking, and insurance are also expected to be liberalized. The results here found that these two sectors have huge scope to generate benefits across ASEAN and its neighbors.

The rest of the chapter is organized as follows. Section 2 reviews existing studies. Section 3 explains the methodological framework, data, and defined scenarios. Section 4 discusses the results. The chapter concludes with a summary of the findings and offers several policy suggestions.

\section{LITERATURE REVIEW}

The services sector is the next frontier in trade liberalization, with progress likely to bring enormous economic benefits to ASEAN. However, one major impediment is the lack of rigorous analytical work on its potential impact. Existing studies adopt different types of modelling to address the impact and consequences of liberalizing services trade. CGE models are often used to assess economy-wide effects of trade liberalization - which can be useful in policy deliberations.

Restrictions on services trade are far more complex than those on goods. Fukui and McDaniel (2010) described a set of stylized facts using CGE modelling research: they found that: (i) barriers to services trade are complex and heterogeneous across sectors; (ii) services have significant effects on downstream industries; (iii) market structure assumptions are crucial; (iv) foreign presence is often necessary for services trade; and (v) entry or fixed-cost barriers that restrict new foreign and domestic entrants are common. Benjamin and Diao (2000) studied services trade liberalization in the Asia-Pacific Economic Cooperation (APEC) forum using a global, multi-country, multi-sector applied general equilibrium model with an imperfectly competitive services sector. They applied the reduction in nontariff barriers in services by eliminating the possibility of price-discriminating oligopolistic firms between client countries within APEC. The results suggest that liberalizing services trade reinforces exist- 
ing sectoral trade balances. More advanced APEC members gained the most from services trade liberalization, while developing economies gained more only if tariffs were eliminated.

Jensen et al. (2007) modelled the Russian Federation's potential accession to the WTO, including explicit treatment of foreign direct investment. They estimated economic welfare gains equivalent to $11 \%$ of GDP, and found FDI a key channel of economic benefit. In related work, Rutherford et al. (2005) found that real income effects from liberalization increased from $2 \%$ to $25 \%$, with a decomposition of the results indicating liberalizing FDI was a principal component of welfare gains. In later work, Jensen et al. (2008) highlighted the importance of coordinated domestic regulations and trade reform in services. They used a CGE model to assess the potential impact of liberalizing regulatory barriers against foreign and domestic service providers in Tanzania. They found that the largest gains derived from liberalizing 12 nondiscriminatory barriers. In addition, their model illustrated that greater access to business services improved labor and capital productivity across all sectors of the economy - and that, in the long run, the increased productivity of capital induced capital accumulation and increased capital stock, which in Tanzania resulted in a general expansion in manufacturing.

Chadha et al. (2000) used a CGE model to assess the impact of future services trade liberalization on India's economy. They found that barriers to services trade were likely to be more complex than tariff barriers. They estimated that India's real income would rise $1.6 \%$ after services trade reform. Also using a CGE model, Robinson et al. (2002) evaluated the impact on the world economy of liberalizing services trade as technology transferred from developed countries to developing economies. They found that services trade liberalization not only directly affected global services production and trade, but also had significant implications for other economic sectors. Developed countries gained relatively more from increasing services exports compared with developing countries, while developing economies gained more from increased access to developed country markets for their manufactured export. Trade liberalization also affects an economy through growth in total factor productivity-induced by intermediate inputs, capital goods, and professional services imported into developing countries from advanced economies.

Whalley (2003) assessed quantitative studies on the potential effects liberalizing services trade has on developing countries. He highlighted the importance of firm and worker mobility, the heterogeneity of services, and the relatively large effect of capturing capital flows, typically in the form of FDI. In their study on Tunisia, Konan and Maskus (2006) also used CGE to quantify the economy-wide effects of services trade liberalization, focusing 
on foreign investment in services. Their results showed that removing barriers against FDI was an essential component of potential welfare gains.

Few studies deal with ASEAN trade and investment liberalization. Ishido (2011) investigated the degree of liberalization of ASEAN services trade under four FTAs. The study found that effects differ greatly between sensitive and less sensitive sectors, and that there were sector-wide similarities across countries in commitments under each FTA studied. Dee (2012) mapped policy space in three key service sectors - air transport, maritime services (both shipping and port services), and telecommunications - attempting to find evidence on whether ASEAN Single Windows help achieve the broader revised Kyoto Convention objectives on customs procedures.

This chapter helps determine what is needed in each ASEAN member to effectively liberalize services trade. Most ASEAN countries are relatively transparent about their trade regulations. Yet very few assess the results of reforms, for example, in the time needed to clear customs.

\section{ANALYTICAL FRAMEWORK}

The GTAP CGE modelling framework is one of the best ways of analyzing the economic consequences of multilateral trade agreements, as it integrates national, regional, and global linkages both by product and input markets. A CGE model consists of a system of equations that describes an economy as a whole and the interactions among its various parts. The equilibrium obtained from CGE models satisfies important macroeconomic and market clearing constraints like the equality of aggregate supply and demand for goods and services, full employment, and capital stock and equality/ratio of national or global savings to investment. The structure of the GTAP model is specified and described in Hertel (1997) and Mukhopadhyay and Thomassin (2010, p.209). The model includes industries, households, governments, and global links across economies through trade. Prices and quantities are generated simultaneously in both factor and commodity markets. These models begin by classifying variables in the equation as exogenous and endogenous (Burfisher 2012). The details of the model are described in Appendix 4A.1.

Experiments in CGE modelling are conducted by creating shocks to exogenous variables - by creating disequilibrium-in the models. The CGE model equations then determine new values for all the endogenous variables, creating a new equilibrium where supply across the economy once again equals demand at a new set of prices. The simulations give comparative static results - the models study the impact that changes in exogenous parameters (shocks) have on allocating goods among consum- 
ers and resources among productive activities, along with the consequences for economic efficiency. The models compare alternative equilibrium states without considering the path between the two states. Thus, the models do not have an explicit time dimension. They are used to represent different time frames by changing the microeconomic elements of the closure. ${ }^{7}$ The results of static simulations are often interpreted as representing what the economic system would look like if the new policy had been in place in the base year after relevant adjustments had taken place (Gilbert 2001).

This chapter uses the GTAP database, which includes input-output tables, bilateral trade flows, transport costs, information on tariff and nontariff barriers, and all other data included in the Social Accounting Matrices (SAM) used in CGE models (Burfisher 2012).

A standard GTAP model selects exogenous variables assuming there is full employment in factor markets. This is a neoclassical approach whereby the endowments of productive factors are fixed, allowing market prices to adjust so as to maintain full employment. But full employment is rarely achieved in the real world, particularly for unskilled labor in developing countries. ${ }^{8}$ Hence, the simulations conducted here replace the assumption of full employment with unemployment for unskilled labor for all the countries/regions under consideration. This is done by swapping the fixed endowment of unskilled labor in all ASEAN countries and India, the PRC, Japan, and the Republic of Korea with fixed real wages of unskilled labor. ${ }^{9}$ Thus, market prices of unskilled labor no longer adjust to ensure full employment, but instead capture unemployment with respect to unskilled labor in each economy.

\subsection{Data Aggregation}

As the main purpose here is to analyze the possible economic impact of liberalizing ASEAN service trade, aggregation is done on the original database. The 129 regions in the original database were aggregated into 14 regions with a focus on ASEAN. ${ }^{10}$ In addition to regional aggregation, sectors in the GTAP 8 database are aggregated based on the proposed service tariffs used (Narayanan et al. 2012). With the broad disaggregation of service sectors considered, ${ }^{11}$ the original 57 sectors are aggregated into 30 sectors. The detail aggregation scheme of regions and sectors are given in Appendix 4A.2.

\subsection{Experimental Design}

Six scenarios were simulated to analyze the impact of services trade liberalization within ASEAN. The initial benchmark equilibrium was based 
on the 2007 model to create counterfactual equilibrium benchmarksthe Business as Usual (BAU) scenario-for 2014 and 2030 through a recursive process using estimated macroeconomic variables (Fouré et al. 2010). ${ }^{12}$ New structures are generated for 2007-2014 and 2014-2030 using macroeconomic shocks for the key variables. The exogenous shocks include capital, population, skilled labor, unskilled labor, and total factor productivity. The projection of each economy to 2014 is made using the actual growth rate for each variable. The projection growth rate for total factor productivity for non-agricultural sectors is sourced from Fouré et al. The growth rate for total factor productivity for agriculture is based on the estimations of Ludena et al. (2007). The population growth rate projection was taken from United Nations (2012). Growth rates for skilled labor, unskilled labor, and capital are taken from Fouré et al. GDP is endogenously determined to accommodate the combination of these exogenous shocks.

Results provide a projection for the global economy in 2014 that is in equilibrium. The forecast economy in 2014 is the starting point for subsequent simulation exercises. This forecasting procedure is also applied to update each economy studied to 2030 .

Actual tariff equivalents of nontariff barriers on services applied on the model come from Lee and Itakura (2013) before reducing barriers. $A d$ valorem tariff equivalents of nontariff barriers in nine service sectors are computed as weighted averages of the gravity-model estimates of Wang et al. (2009) and the values employed by the Michigan Model of World Production and Trade (see, for example, Brown et al. 2010). The full reduction in service trade barriers was applied to six scenarios at 2030:

1. S-ASEAN—tariff reductions of selected service sectors within ASEAN;

2. S-ASEAN+3-tariff reductions of selected service sectors within ASEAN and between ASEAN and the PRC/Japan/Republic of Korea;

3. S-ASEAN+Japan - tariff reductions of selected service sectors between ASEAN and Japan;

4. S-ASEAN+Republic of Korea-tariff reductions of selected service sectors between ASEAN and the Republic of Korea;

5. S-ASEAN+PRC - tariff reductions of selected service sectors between ASEAN and the People's Republic of China; and

6. S-ASEAN+India-tariff reductions of selected service sectors between ASEAN and India. 


\section{RESULTS AND DISCUSSION}

This section examines six scenarios of how ASEAN countries would be affected by liberalizing services trade. Figures 4.1 to 4.6 show the impact service trade liberalization would have on output, exports and imports in 2030, as well as its implications on employment generation for skilled and unskilled labor in the member countries.

\subsection{Economic Impact}

Reducing barriers to services trade within ASEAN (scenario 1) has a significant positive impact on output in all ASEAN countries. Total ASEAN output in 2030 under scenario 1 increases $\$ 295.8$ billion $(10.2 \%)$

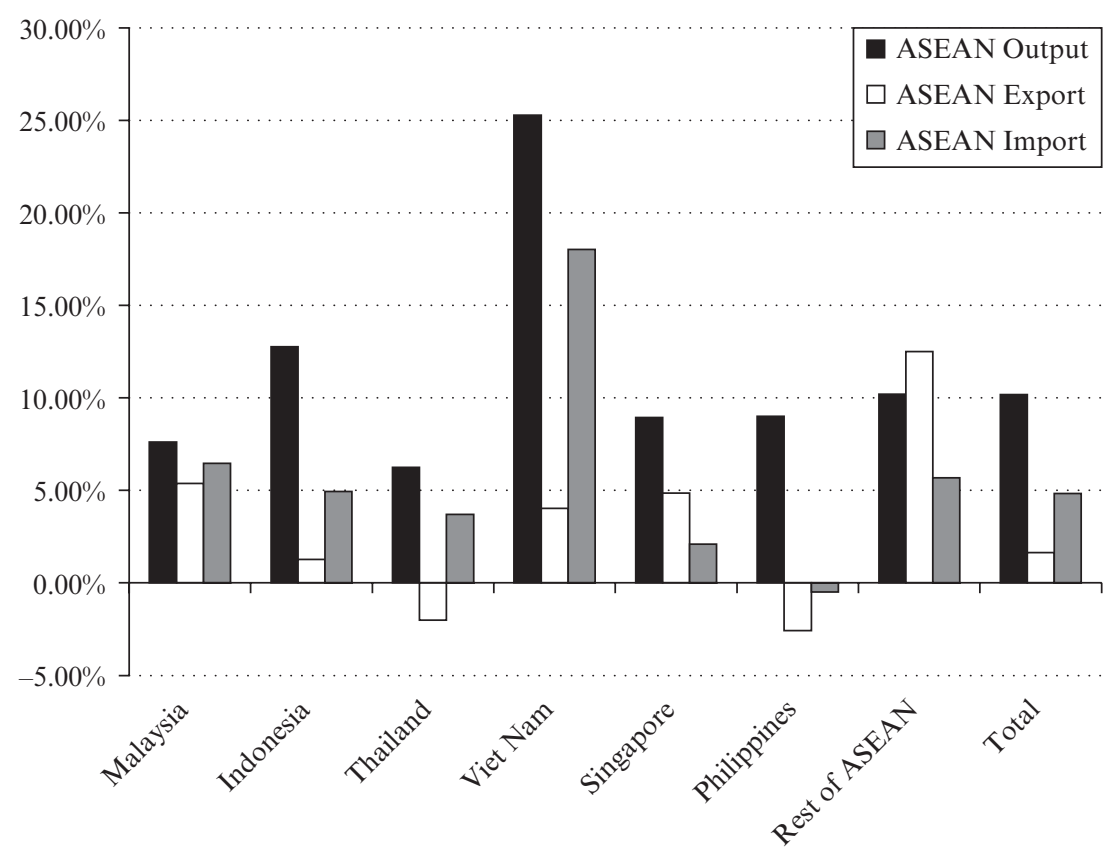

Note: $\quad *$ S-ASEAN $=$ tariff reductions of selected service sectors within ASEAN compared with Business as Usual (no liberalization).

Source: Author's calculations.

Figure 4.1 Scenario 1 -impact of service trade liberalization in 2030 within ASEAN compared to BAU 2030* (\%) 


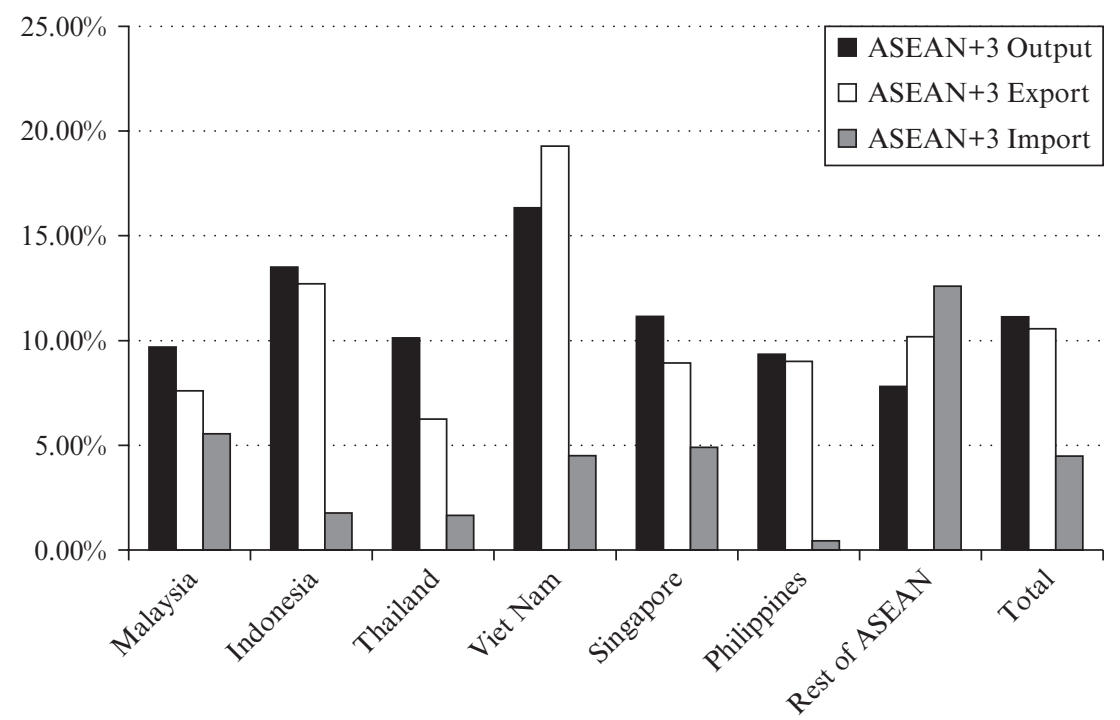

Note: $*$ S-ASEAN $+3=$ tariff reductions of selected service sectors within ASEAN and between ASEAN and the People's Republic of China, Japan and the Republic of Korea compared with Business as Usual (no liberalization).

Source: Author's calculations.

Figure 4.2 Scenario 2 - impact of service trade liberalization in 2030 within ASEAN+3 compared to BAU 2030* (\%)

above the BAU 2030 scenario. Indonesia contributes most, with output rising $\$ 107.4$ billion (up $12.8 \%$ ). Viet Nam's output increases $\$ 38.5$ billion $(25.3 \%)$. Service tariff reductions among the +3 countries in addition to intra-ASEAN service liberalization (scenario 2) would also have significant impact. Output under scenario 2 increased $11.1 \%$ above the BAU 2030 benchmark, slightly higher than the increase under scenario 1. Under the ASEAN+3 scenario, Viet Nam's output rises 16.3\%, followed by Indonesia, Singapore and Thailand.

ASEAN countries could expect an additional $4.2 \%$ growth in output under the ASEAN-Japan service trade liberalization scenario 3. Singapore shows the highest growth $(8.15 \%)$, while the Rest of ASEAN would grow slowest $(2.62 \%)$.

Under the ASEAN-Republic of Korea scenario 4, ASEAN's total output growth rises $4.83 \%$. The highest growth is in Indonesia $(6.89 \%)$, followed by the Philippines, Singapore and Thailand. 


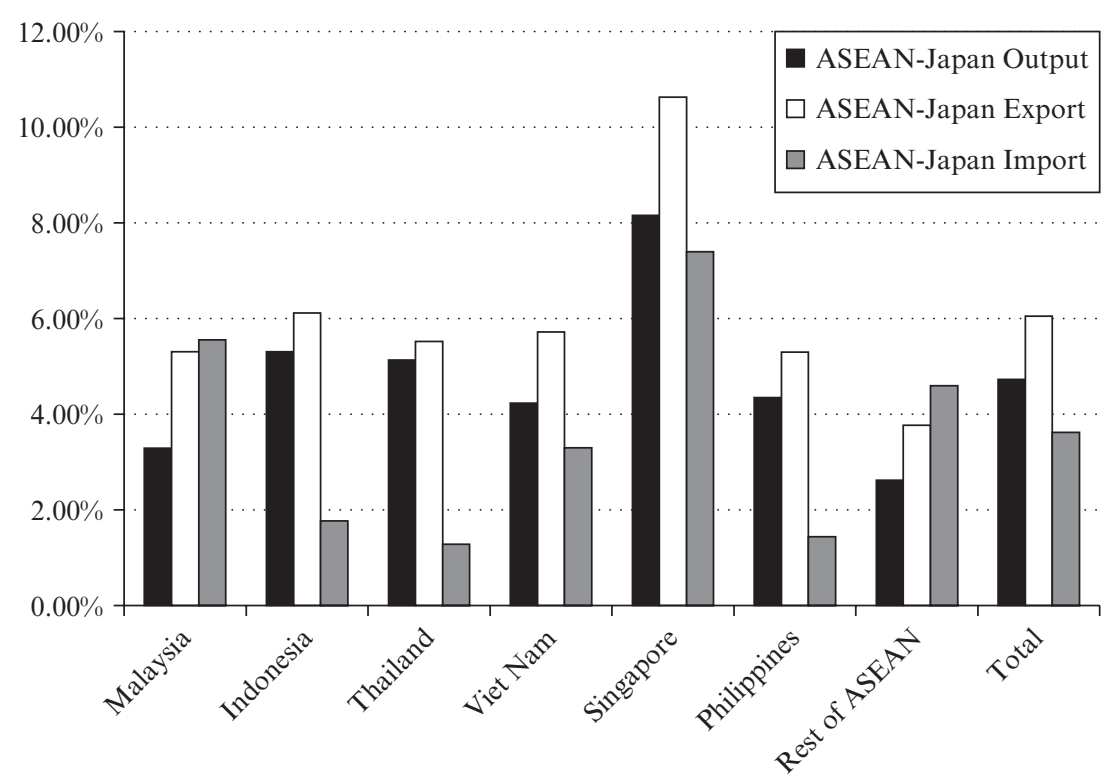

Note: $*$ S-ASEAN + Japan $=$ tariff reductions of selected service sectors between ASEAN and Japan compared with Business as Usual (no liberalization).

Source: Author's calculations.

Figure 4.3 Scenario 3-impact of service trade liberalization in 2030 within ASEAN and Japan compared to BAU 2030* (\%)

A 3.99\% increase in output growth is expected for ASEAN in the case of the ASEAN-PRC scenario 5. Singapore rises $7.12 \%$, with the lowest growth in Malaysia (2.14\%). The rest of ASEAN ranges from 3.56\% to $4.65 \%$.

Under the ASEAN+India scenario 6, most ASEAN countries gain from services trade liberalization. The expected output growth is most noticeable in Singapore (8.34\%), Viet Nam (7.29\%) and Indonesia (6.34\%).

\subsection{Sectoral Output Impact}

Analyzing changes in output by sector shows that, as might be expected, service ${ }^{13}$ get the biggest boost from a cut in service tariffs. In the S-ASEAN scenario 1, the services sector sees the largest increase in output in all ASEAN members when compared with the BAU 2030 benchmark. In Indonesia, services output rose the most ( $\$ 89.8$ billion). However, output 


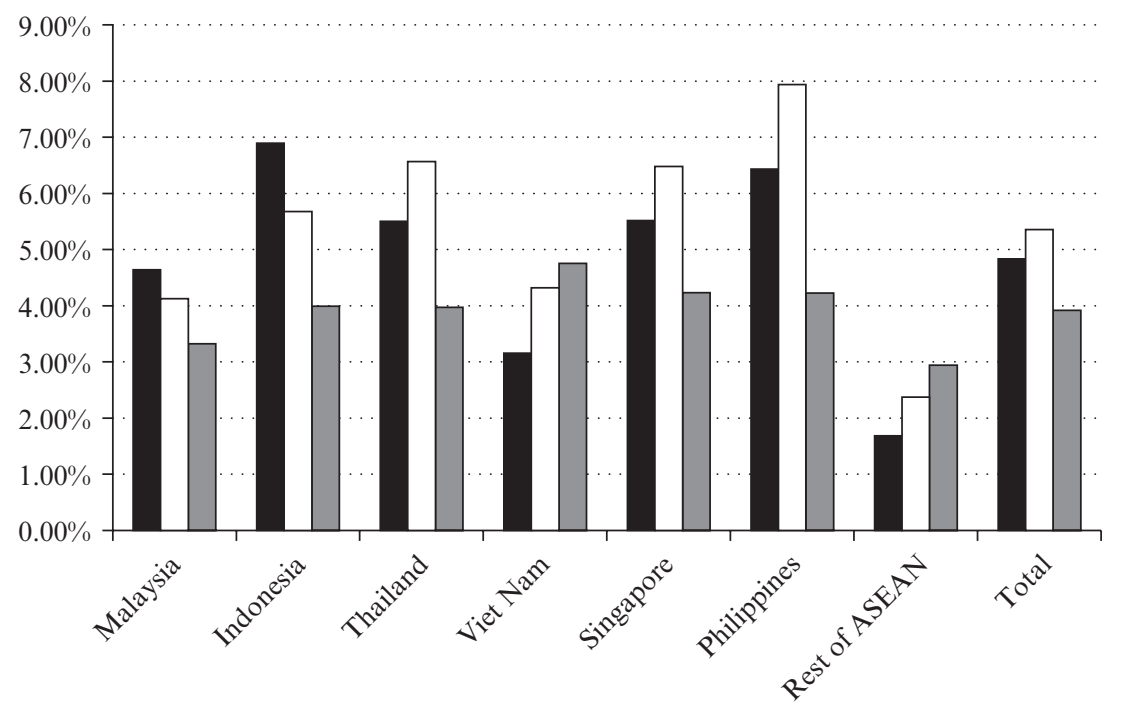

ASEAN-Rep. of Korea Output $\square$ ASEAN-Rep. of Korea Import $\square$ ASEAN-Rep. of Korea Export

Note: $*$ S-ASEAN + Republic of Korea $=$ tariff reductions of selected service sectors between ASEAN and Republic of Korea compared with Business as Usual (no liberalization).

Source: Author's calculations.

Figure 4.4 Scenario 4-impact of service trade liberalization in 2030 within ASEAN and the Republic of Korea compared to BAU $2030^{*}(\%)$

in several other sectors decline under scenario 1. For example, output in petroleum and coal products in Singapore and Indonesia drops $\$ 2.2$ billion and $\$ 1.8$ billion respectively. In Thailand, chemicals, rubber and plastics decline \$2.9 billion, while the electronics sector in the Philippines decreases $\$ 1.5$ billion. Nonetheless, these reductions are far smaller than the gains in overall services output. Additional tariff reduction under the S-ASEAN+3 scenario 2 did not appear to have any significant sectoral impact. In Indonesia, services output increased $\$ 2.1$ billion. Overall, a similar services sector growth pattern was observed in the case of scenarios $3,4,5$, and 6 . However, a much bigger impact is seen on transport and financial services. Among service subsectors, the highest output increase occurs in financial services under the ASEAN-Japan scenario 3, construction and utilities in 


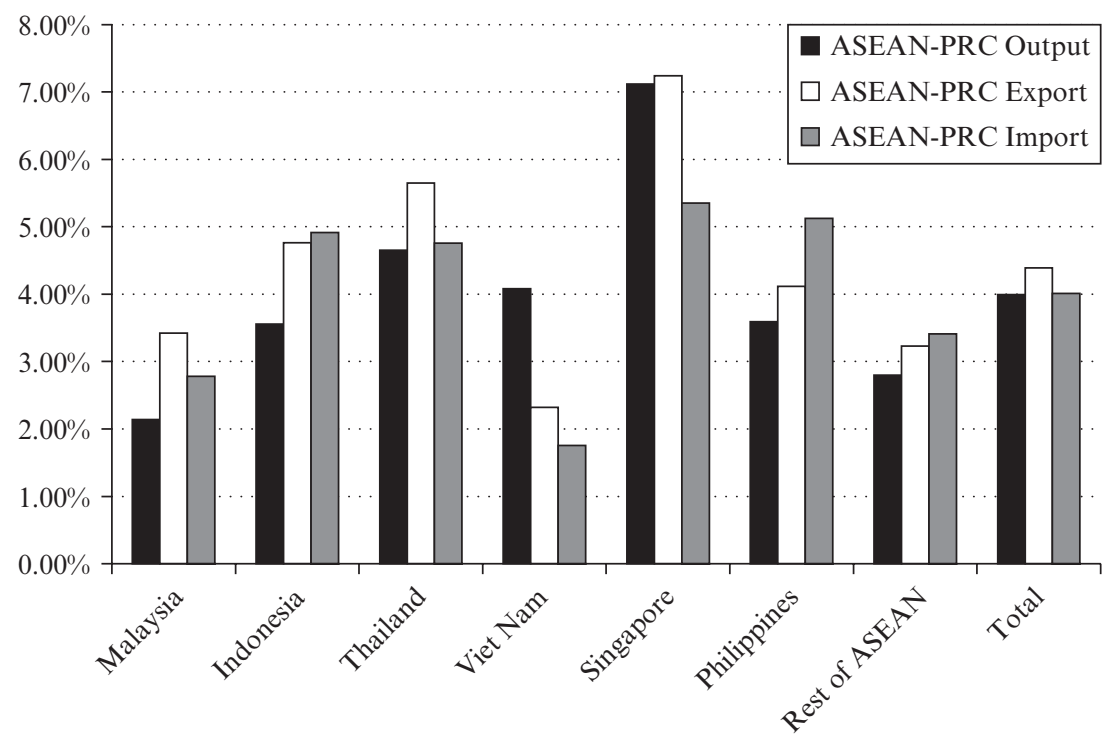

Note: $*$ S-ASEAN + PRC $=$ tariff reductions of selected service sectors between ASEAN and the People's Republic of China compared with Business as Usual (no liberalization).

Source: Author's calculations.

Figure 4.5 Scenario 5-impact of service trade liberalization in 2030 within ASEAN and the People's Republic of China compared to $B A U 2030^{*}(\%)$

the ASEAN-Republic of Korea scenario 4, and trade and transportation under ASEAN-PRC scenario 5.

\subsection{Trade Impact}

The tariff reductions under the six scenarios show that liberalizing services trade will have a small but positive impact on exports and imports. ASEAN exports rise $\$ 14$ billion (1.65\%) under the S-ASEAN scenario 1 compared with the BAU 2030 benchmark. The impact on individual countries, however, varies significantly. Malaysia, Singapore and the Rest of ASEAN see exports increase significantly, growing $5.4 \%, 4.9 \%$ and $10.2 \%$, respectively. Exports from the Philippines and Thailand, on the other hand, would decline marginally. The additional tariff reductions applied under the S-ASEAN+3 scenario 2 does not have much additional impact. Total ASEAN exports rise $\$ 26.1$ billion 


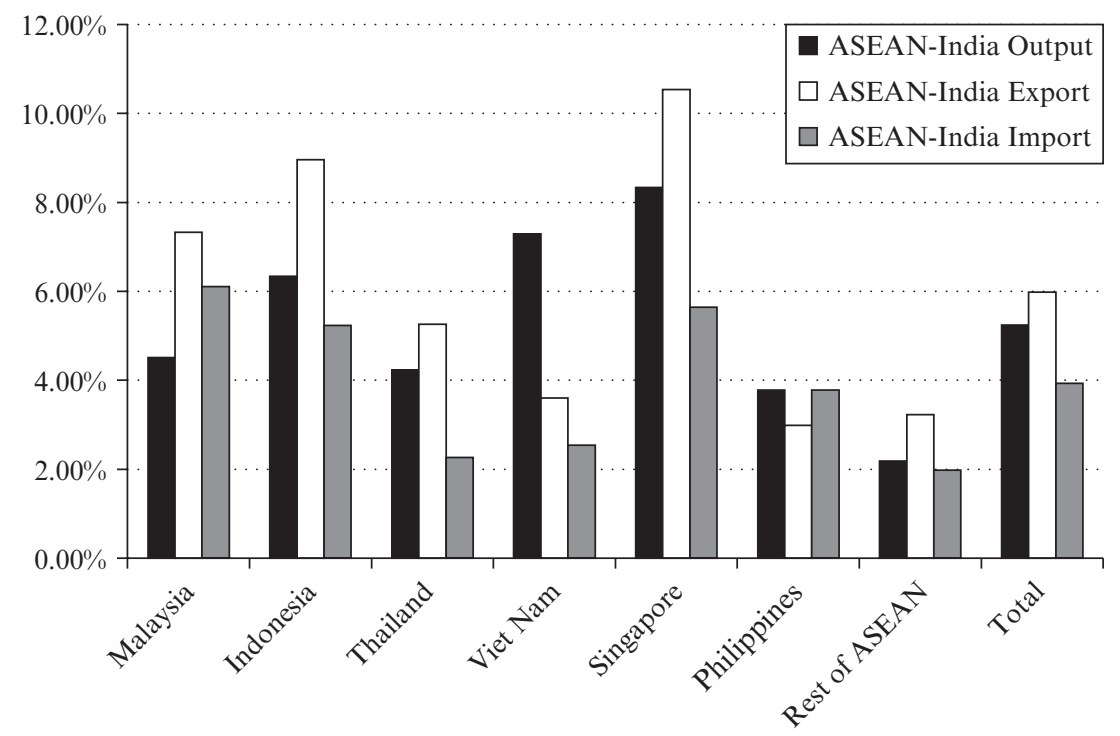

Note: $*$ S-ASEAN + India $=$ tariff reductions of selected service sectors between ASEAN and India compared with Business as Usual (no liberalization).

Source: Author's calculations.

Figure 4.6 Scenario 6-impact of service trade liberalization in 2030 within ASEAN and India compared to BAU 2030 (\%)

and \$2.1 billion compared with the BAU 2030 benchmark and S-ASEAN scenario 1, respectively. Most ASEAN members, including the Philippines and Thailand, gain in exports. Viet Nam receives the highest export boost under the S-ASEAN+3 scenario 2 (up 19.27\%), with other members' exports increasing from $6.25 \%$ to $10.18 \%$ (Indonesia's exports rise $12.71 \%$ over the benchmark). The ASEAN-Japan scenario 3 receives an additional $6.05 \%$ export boost, while the ASEAN-Republic of Korea and ASEAN-PRC scenarios 5 and 6 also show export growth of $5.35 \%$ and $4.39 \%$ respectively. Singapore gained in terms of exports from the ASEAN-Japan and ASEAN-PRC scenarios 3 and 5, while the Philippines increases exports under the ASEAN-Republic of Korea scenario 4. Under the S-ASEAN+India scenario 6, Singapore's exports gain $10.54 \%$, followed by Indonesia (8.96\%) and Malaysia (7.33\%).

The benefits under the ex-ASEAN scenarios show some variations. For example, services trade volumes between Japan and ASEAN are considerably smaller than merchandise trade. However, Japan's services exports to 
ASEAN are more than its imports. Japan-ASEAN services trade remains highly concentrated on Singapore, which accounts for more than half of both exports and imports of services between Japan and ASEAN.

ASEAN is the Republic of Korea's second-largest trading partner after the PRC. Two-way trade between the Republic of Korea and ASEAN - \$131 billion in 2012-benefited substantially from AKTIS. ASEAN is the Republic of Korea's top foreign investment destination. In 2012, the Republic of Korea invested $\$ 4.3$ billion in ASEAN. The top two destinations for the Republic of Korea's FDI to ASEAN were the Philippines and Indonesia.

Under scenario 4, ASEAN's share of the Republic of Korea's services exports increases $15 \%$, while imports of services from ASEAN rises 13\%. It is also clear from historical trade data that the Republic of Korea's services trade with ASEAN has consistently grown since 2006. Most ASEAN countries-Indonesia, Malaysia, the Philippines, Singapore, Thailand and, to some extent, Viet Nam—-benefit from AKTIS.

\subsection{Sectoral Trade Impact}

A sectoral-level analysis of the changes in ASEAN exports under the six scenarios show different sectors react differently across countries. Results reveal that most services exports under the five ASEAN+ scenarios increase compared with the benchmark BAU and S-ASEAN scenarios. In the S-ASEAN scenario 1, Singapore's $\$ 9.8$ billion growth in services exports was more than double the $\$ 4.3$ billion drop in petroleum and coal product exports. Services would gain most $-\$ 9.5$ billion in exports over the BAU scenario, the largest component of Singapore's export growth.

Electronics also played an important part in export gains in Malaysia and Indonesia, growing $\$ 5.8$ billion and $\$ 4.5$ billion, respectively under S-ASEAN scenario 1. Similar trends are seen under S-ASEAN+3 scenario 2 , but with much smaller gains compared with the S-ASEAN scenario 1 - \$198 million for Malaysia and \$233 million for Indonesia. These results indicate that indirect effects of tariff reductions under S-ASEAN and S-ASEAN +3 scenarios 1 and 2 are behind the rise in export volumes.

Financial services are an important component of Japan-ASEAN trade in services (scenario 3). In fact, financial services are key to overall trade competitiveness and entry into global value chains. Malaysia, Indonesia and Singapore show important gains. This is true for services itself as well as for manufacturing and production activities where services are inputs. Although Japan has invested in ASEAN services like banking and logistics (Biswas 2014), there remains huge potential for further liberalizing services trade in both directions (Sato 2014). Thus far, however, liberalizing 
ASEAN services trade has been far less successful than liberalizing trade in goods (Versetti and Heal 2015).

Construction, utilities, and other private and government services play a key role in ASEAN-Republic of Korea trade (scenario 4). Currently, the Republic of Korea exports significant amounts of construction services to ASEAN. ASEAN is also the Republic of Korea's second most popular tourist destination (after the PRC). Thus, so far, construction, banking and tourism have seen the biggest boost from AKTIS. This is particularly true for Malaysia, Indonesia and the Philippines (Tongzon and Cheong 2016).

The Republic of Korea is expected to export more construction services to Malaysia, while Malaysia will export more healthcare and tourism services to the Republic of Korea. GTAP categorizes healthcare and tourism under "other private and government services." These subsectors are covered by AKTIS with substantial liberalization commitments from both sides. Thus, it is likely growing trade flows in these subsectors will flow from AKTIS. But the increase in tourists visiting the Philippines and Philippine professionals migrating to work in the Republic of Korea was unlikely due to AKTIS. Financial sector exports between the Philippines and the Republic of Korea likely increased due to AKTIS. AKTIS has also led to more robust trade with Singapore. Two-way trade between Singapore and the Republic of Korea has also grown due to their bilateral FTA, which came into force in 2006 (Tongzon and Cheong 2016).

In ASEAN, many sectors have gained since the 2007 PRC-ASEAN trade in services agreement. The ASEAN-PRC scenario 5 shows that construction, sea transportation, communications and financial services will increase for the PRC, while air and sea transportation, communications, financial services, construction and utilities, and other private and government services will grow for ASEAN members.

Currently, half of PRC-ASEAN trade is carried by sea-trade volumes increased $22.7 \%$ since 2010 and will likely continue to expand. As trade increases, so should financial services (Yang 2009).

The PRC-ASEAN services agreement has increased services trade, although differences in development among ASEAN members lead to varying gains. For example, Singapore attracts investments in knowledgeintensive services, while it invests in high-technology services-such as construction, electric power and "eco cities" in the PRC.

For ASEAN-India services trade (scenario 6), the results support the findings of the Deloitte and Federation of Indian Chambers of Commerce and Industry joint study (East Asia Forum 2013), which showed that computer and information services, telecommunications, e-commerce and engineering services will benefit India. Financial and insurance services will 
benefit both, while ASEAN members would benefit more in construction, engineering, shipping and transportation services. ASEAN investment in India would likely concentrate in energy, transport and logistics. Overall, India has an advantage in the services sectors over the ASEAN nations.

The effect of trade liberalization on imports is also significant. In the S-ASEAN scenario 1, total imports into ASEAN increases $4.8 \%$ over the BAU 2030 benchmark. Most ASEAN countries see imports rise. Viet Nam has the largest increase, $\$ 12.6$ billion (18.0\%), followed by Malaysia at $\$ 9.9$ billion (6.5\%). The Philippines would see a marginal rise of $\$ 1.7$ billion. Additional tariff reduction in the S-ASEAN +3 scenario 2 has a marginal $(2.7 \%)$ rise in imports over the benchmark. Imports into the Rest of ASEAN, Viet Nam and Malaysia increase 2.3-5\% over the BAU2030 benchmark, while imports into the Philippines decline less than $1 \%$. In the case of the ASEAN-India scenario 6, ASEAN's additional import growth ranges between $2.2 \%$ and $6.4 \%$.

Services and machinery equipment dominate the increase in imports into most ASEAN nations under the S-ASEAN and S-ASEAN+3 scenarios 1 and 2. In Thailand, imports of services rise $\$ 7.0$ billion-the largest share of the increases. Services are also highest in Indonesia, Viet Nam and Singapore. In Malaysia and the Philippines, machinery equipment contributes most to the import increase. In Malaysia, machinery equipment imports rise $\$ 5.3$ billion.

Several sectors show declines under the S-ASEAN import scenario 1. In Singapore, oil declines $\$ 1.3$ billion. In the Philippines electronics decrease $\$ 1.5$ billion. Under the S-ASEAN+3 scenario 2, several sectors increase above the S-ASEAN scenario 1 rise. For example, services imports into Thailand rise $\$ 0.4$ billion, while machinery equipment imports to Malaysia increase marginally (\$23 million).

\subsection{Welfare Impact}

Aside from the increase in output and trade from liberalizing services trade under the six scenarios, ASEAN also receives an overall welfare gain (Figure 4.7). In the S-ASEAN scenario 1, total welfare rises $\$ 4.0$ billion over the BAU 2030 benchmark - though unevenly distributed. Indonesia captures the largest gain ( $\$ 860$ million), followed by Malaysia ( $\$ 796$ million) and Viet Nam (\$716 million). Under the ASEAN+3 scenario 2, ASEAN members gain $\$ 6.6$ billion. Viet Nam gains most ( $\$ 1.2$ billion), followed by Singapore and Indonesia (both $\$ 1.2$ billion).

Welfare gains in Indonesia are primarily in technology, while in Singapore it is in terms of trade. Much larger welfare gains accrue under the S-ASEAN+3 scenario 2, despite the marginal effects on output, 


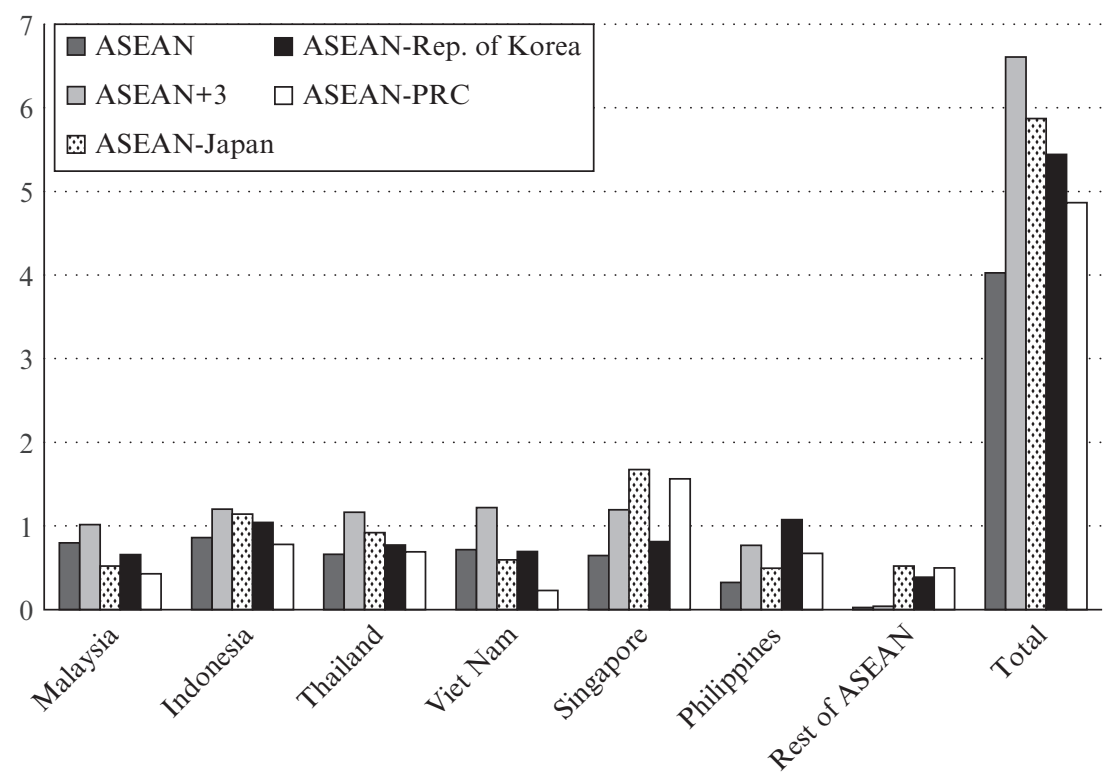

Note: $\quad$ ASEAN $=$ Association of Southeast Asian Nations, BAU $=$ Business as Usual, PRC $=$ People's Republic of China.

Source: Author's calculations.

Figure 4.7 Welfare change under scenarios 1-5 compared with the BAU 2030 benchmark (\$ billion)

exports and imports. Most of the additional welfare gains flow to Viet Nam, while the total for Thailand, Indonesia and Singapore is $\$ 1.1$ billion.

The other scenarios also show welfare gains considerably above the S-ASEAN scenario 1. The highest welfare gain flows from the ASEANJapan scenario 3 ( $\$ 5.8$ billion), followed by the ASEAN-Republic of Korea scenario 4 ( $\$ 5.4$ billion). Welfare gains under the ASEAN-PRC and ASEAN-India scenarios 5 and 6 are also significant (above $\$ 4$ billion). With the exception of the ASEAN-Republic of Korea scenario 4, Singapore leads in welfare gains followed by Indonesia. Under scenario 4, the Philippines receive the most significant welfare gain ( $\$ 1.1$ billion). The main source of welfare gains remains technology. Singapore is expected to gain most under the ASEAN-India scenario (Figure 4.8). 


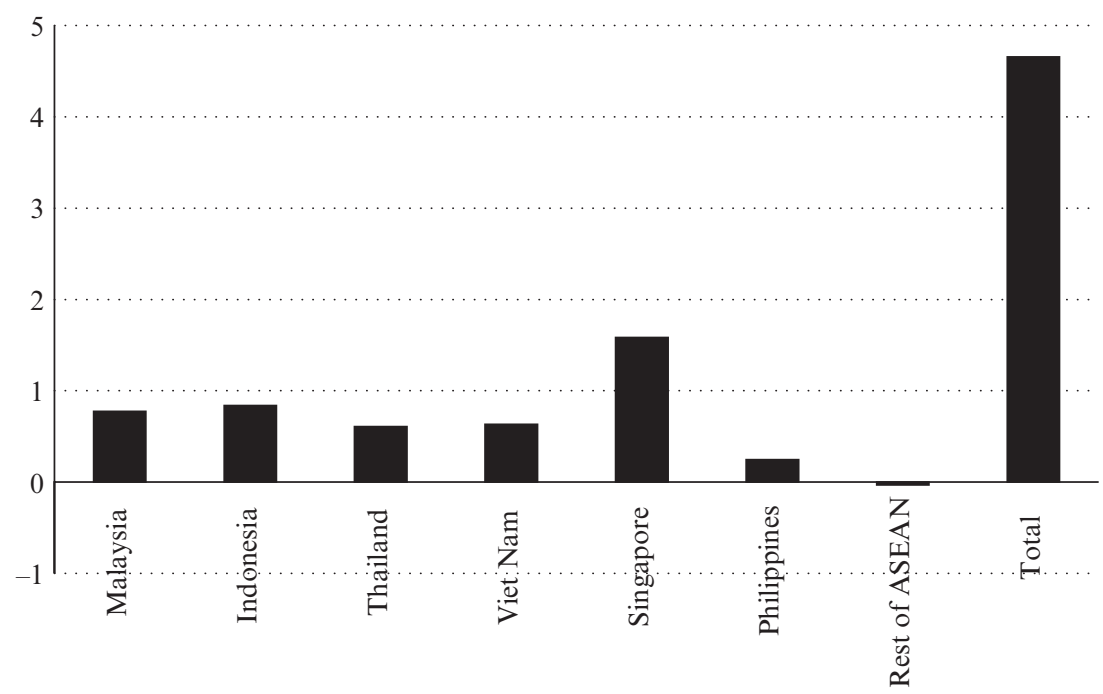

Note: $\quad$ ASEAN $=$ Association of Southeast Asian Nations, BAU $=$ Business as Usual.

Source: Author's calculations.

Figure 4.8 Welfare change under the ASEAN-India scenario 6 compared with the BAU 2030 benchmark (\$ billion)

\subsection{Social Implications-Skilled vs. Unskilled Labor}

Service trade liberalization is expected to have a considerable impact on employment. The removal of service trade barriers would significantly benefit the ASEAN population as it would lead to greater specialization and division of labor - as each member concentrates on producing goods and services where it holds comparative advantage (see Appendix 4A.3). Liberalizing services trade would have both positive and negative effects depending on a member's employment structure. For example, higherincome groups may benefit from more highly competitive markets as they expand production networks. In Thailand, the largest increases are projected for retail sales and semi-skilled services linked to high trade and transport growth. Unskilled workers - many of whom would be employed in the informal sector-also gain. ${ }^{14}$ The highest projected wage growth rates fall under a variety of occupations related to trade, transport and construction in the Philippines, Indonesia and Viet Nam.

Employment gains vary widely across scenarios and by country (Table 4.1). Singapore is expected to gain most in skilled-labor employment 


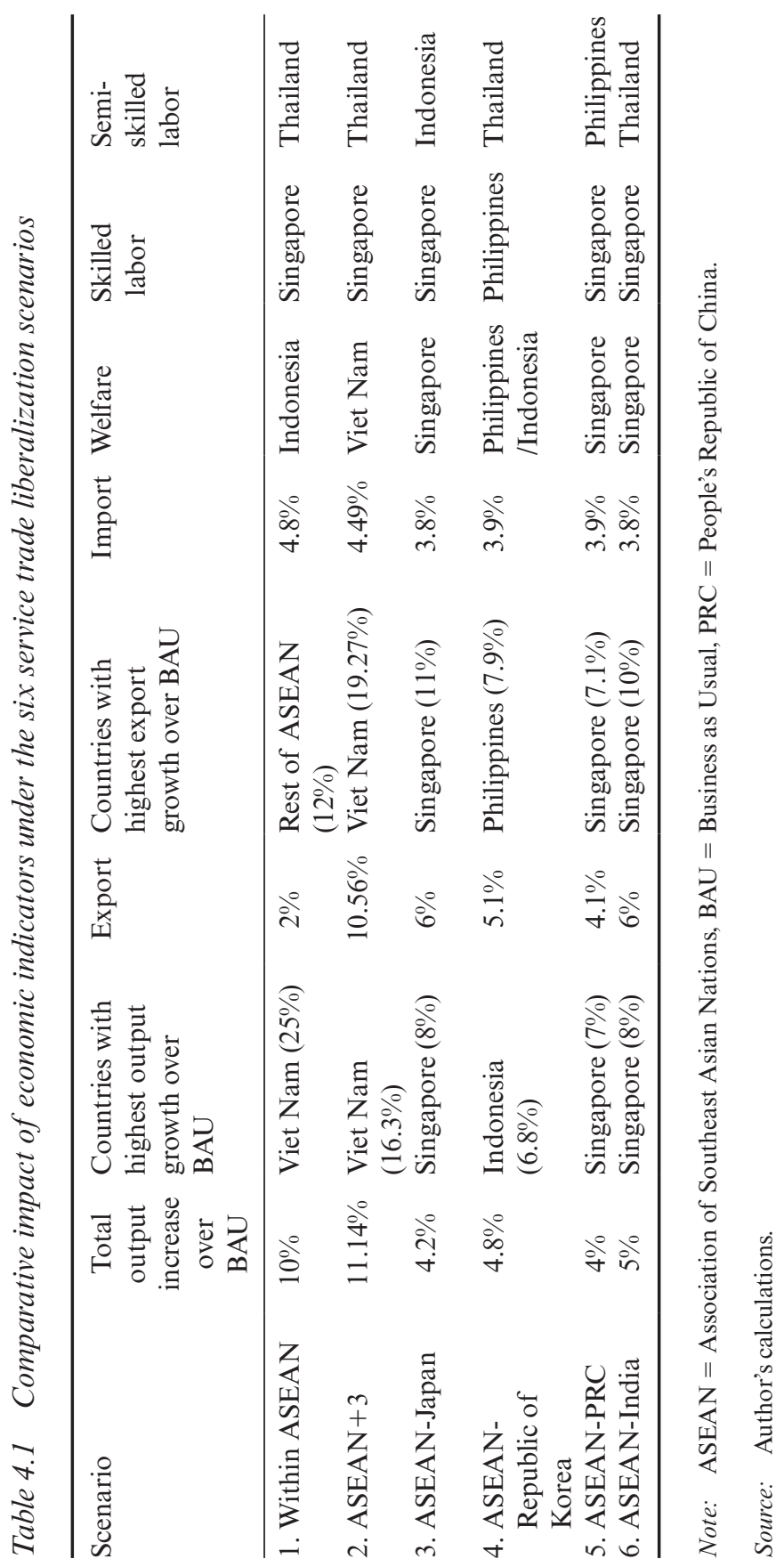


under most scenarios (scenarios 1, 2, 3 and 6). Appendix 4A.3 shows the extent to which additional skilled employment generation rises in comparison with other ASEAN countries. This makes sense given Singapore's high-skill production base - it accounts for half the total volume of highskill manufacturing exports. Singapore's high-skill technology-intensive manufactured exports rose from 36\% to $48 \%$ between 2000 and 2012. The impact on unskilled labor is marginal.

Compared with other ASEAN members, Thailand and the Philippines see relatively high employment generation for skilled laborers. The Philippines also appears to have the highest skilled employment generation under the ASEAN-Republic of Korea scenario 4. It also has highest employment gains for unskilled labor under most scenarios. Thailand shows significant positive gains in employment in both skilled and semiskilled sectors under the various scenarios. The gains are equal under the ASEAN-Republic of Korea scenario 4. Skilled laborers benefit more under the ASEAN-Japan, PRC and India scenarios (3, 5 and 6).

Indonesia's employment generation is minimal under the ASEAN scenario 1, but shows the largest gain for semi-skilled workers under the ASEAN-Japan scenario 3. In general, the results across ASEAN are in line with the levels of skilled versus semi-skilled labor these members produce.

It is important to note, however, that in less-developed ASEAN members, many high-skilled employment opportunities are filled by inadequately qualified laborers. This widens the scope for inefficiency and a potential productivity gap in the services - an argument for the low absolute numbers generated by the GTAP model against the BAU 2030 benchmark. As the analysis indicates, Singapore is expected to gain most under the various scenarios, with Viet Nam and Indonesia also likely to benefit under several scenarios.

\section{CONCLUSION}

The ASEAN region is one of the most dynamic, rapidly growing regions in the world. The Asian Development Bank projects that Indonesia, Malaysia, the Philippines, Thailand and Viet Nam - with a population of 525 million and a $\$ 2.8$ trillion combined GDP - are expected to grow almost 6\% per annum between now and 2030. The launch of the ASEAN Economic Community (AEC) in 2015 was an important, significant step in promoting and further accelerating growth within the region by removing tariff barriers between members. Yet, there are few studies that analyze the long-term impact of ASEAN integration focusing on liberalizing service trade. This chapter helps fill this void by assessing its impact on the region. 
The results of the projections here indicate that service trade liberalization within ASEAN would have a significant impact on output and trade. Further, by extending tariff reductions to the +3 nations of the PRC, Japan and the Republic of Korea brings significant added benefits to ASEAN. By 2030, service trade liberalization would increase output by $\$ 29.6$ billion, exports by $\$ 14.0$ billion and imports by $\$ 36.8$ billion over the benchmark Business as Usual scenario. Service sector output in Indonesia would rise by $\$ 89.8$ million, ten times more than the second-highest estimated increase of $\$ 8.9$ million, registered in rice cultivation. This trend is seen throughout ASEAN, indicating that the effect of service tariff cuts is largely limited to services.

Liberalization in services trade also brings welfare gains, although not evenly distributed among members. Extending service tariff reductions to the +3 countries, collectively and individually, results in an additional marginal rise in output, exports and imports, but a much greater boost in welfare. ASEAN+3 agreements also show welfare gains for almost all ASEAN members, particularly Singapore and Indonesia. But despite the complementarities, trade in services between India and ASEAN still faces considerable challenges. The ASEAN-India services and investment agreement provides opportunities for ASEAN nations to access India's markets in energy, transport and logistics, while India can access ASEAN markets in consultancies, software, maintenance and installation, education, health and social work. Employment growth would be the greatest in trade and transport in all countries except the Rest of ASEAN countries, where employment growth would be higher in agriculture and semi-skilled manufacturing.

Large projected employment growth in trade and transport in all countries implies that a large share of this employment growth is linked to the informal sector. These results are not surprising, as any regional integration initiative can be expected to have asymmetric effects on factors of production within and across service industries. These depend on a variety of factors, including the skills structure of the workforce, factor composition of industries, economies of scale and supply chain linkages. In addition, service trade liberalization appears to have a positive impact on employment generation in all ASEAN member countries across all scenarios tested. While Singapore is expected to see the highest generation of skilled employment, Thailand and the Philippines have the highest demand rise for semi-skilled laborers - in keeping with the general orientation of these economies. The analysis of the effect of service trade liberalization on employment leaves questions regarding the scope for raising potential gains through human capital development and enhancing productivity across economic sectors. 
In conclusion, there is great potential for cooperation in service trade between ASEAN, East Asia and India. If all parties work to increase collaboration, standardize resource availability, build systems and coordinate relevant policies there would be a better chance for all members to gain evenly. How this would work best is an area for further study.

\section{NOTES}

* Paper presented at the Workshop "Achieving and Benefiting from Skill Mobility in ASEAN" organized by ADB, Manila on 31 March 2016 and 1 April 2016. The author would also like to thank Dr. Elisabetta Gentile, Dr. Guntur Sugiyarto, and Eric B. Suan for their relevant comments. All errors, if any, lie with the author.

1. http://asean.org/asean-economic-community/sectoral-bodies-under-the-purview-of-aem/ services/.

2. In professional services, domestic regulations are not yet aligned with ASEAN MRAssome required bilateral negotiations to make them operational. In air transport, further liberalization will be needed for a truly integrated regional air transport services market. In finance, ASEAN members are working to deepen financial services integration. There are initiatives to strengthen and harmonize capital market disclosure standards. And the ASEAN Banking Integration Framework (ABIF) aims in part to promote intraregional trade and investment (ASEAN-World Bank 2015).

3. Competitive salaries and low compensation costs, a large pool of qualified talent, low telecommunication and real estate costs, investment incentives, and fostering tertiary education have been keys to its success.

4. Mode IV access refers to the Restriction on Work Permits and Uniform Qualification Recognition under the FTA that allows greater flexibility in obtaining specified longerterm visas and work permits. While Mode IV access may also cover ASEAN MRAs, they may still require further agreements between India and each ASEAN member (https:// www.dfdl.com/wp-content/uploads/2015/04/IPBA_Journal_India-ASEAN_FTA_in_ser vices_and_investments_countdown_to_implementation.pdf).

5. ASEAN Trade Statistics Database as of July 2016.

6. Share of ASEAN in total FDI flow was $21.6 \%$.

7. Neoclassical closure assumes that investment is equalized with savings at a level that guarantees full employment. This rule is essential for the neoclassical model.

8. With the exception of Singapore, all ASEAN members are developing countries.

9. Thus, the endowment of unskilled labor-fixed in a standard GTAP model with market prices adjusting to maintain full employment - is replaced with fixed real wages.

10. The Lao People's Democratic Republic (Lao PDR), Cambodia and the "Rest of Southeast Asia" (Myanmar, Brunei Darussalam and Timor-Leste) comprise "Rest of ASEAN."

11. Construction and utilities, trade, sea transport, air transport, other transport, communications, financial services, other private services and government services.

12. To carry out the desired projections and simulations, it was decided to update the static GTAP model with a 2007 base year to 2030. The process uses recursive updating based on forecasting a country's (region's) economy by exogenously shocking the baseline model with projections of macroeconomic variables.

13. See note 11 .

14. Particularly construction workers. 


\section{REFERENCES}

ASEAN-World Bank (2015), 'ASEAN Services Integration Report: A Joint Report by the ASEAN Secretariat and the World Bank'. Office of ASEAN Secretariat and World Bank-East Asia and Pacific Region.

Benjamin M. and X. Diao (2000), 'Liberalising Services Trade in APEC: A General Equilibrium Model with Imperfect Competition'. Pacific Economic Review, 5(1):49.

Biswas, R. (2014), 'Japan Shifting Investments from China [People's Republic of China] to ASEAN'.www.dw.de/japan-shifting-investments-from-china-to-asean/a $-17809068$.

Brown, D.K., K. Kiyota, and R.M. Stern (2010), 'Computational Analysis of the Menu of U.S.-Japan Trade Policies'. RSIE Discussion Paper No. 611, Ford School of Public Policy, University of Michigan.

Burfisher, M.E. (2012), Introduction to Computable General Equilibrium Models. New York: Cambridge University Press.

Chadha, R, D.K. Brown, and A.V. Deardorff (2000), 'Computational Analysis of the Impact on India of the Uruguay Round and the Forthcoming WTO Trade Negotiations'. Mimeo, University of Michigan.

Dee P. (2012), 'Services Liberalisation: Impact and Way Forward Trade', Paper prepared for ASEAN Economic community Mid Term Review, Jakarta: Economic Research Institute for ASEAN and East Asia.

East Asia Forum (2013), 'India-ASEAN FTA in Services: Good for the Region, Very Good for India', Economics, Politics and Public Policy in East Asia and the Pacific, 30 July.

Fouré, J., A. Benassy-Quéré, and L. Fontagné (2010), 'The World Economy in 2050: A Tentative Picture', CEPII Baseline 1.0. CEPII Working Paper 2010-27.

Fukui, E.T. and A.C. McDaniel (2010), 'Services Liberalization and Computable General Equilibrium Modeling: Beyond Tariff Equivalents'. SSRN: http://ssrn. com/abstract $=1538977$ orhttp://dx.doi.org/10.2139/ssrn.1538977.

Gilbert, J.P. (2001), 'Appendix: GTAP Model Analysis: Simulating the effect of a Korea-US FTA using Computable General Equilibrium Techniques', in I. Choi and J.J. Schott, Free Trade Between Korea and the United States? Washington, DC: Institute for International Economics.

Hertel, T.W. (1997), Global Trade Analysis. Cambridge, MA: Cambridge University Press.

Ishido, H. (2011), 'Liberalization of Trade in Services under ASEAN+n: A Mapping Exercise', ERIA-DP-2011-02 ERIA Discussion Paper Series, APEC Study Center, Faculty of Law and Economics, Chiba University, Japan.

Jensen, J., T. Rutherford, and D. Tarr (2007), 'The Impact of Liberalizing Barriers to Foreign Direct Investment in Services: The Case of Russian Accession to the World Trade Organization', Review of Development Economics 11: 482-506.

Jensen, J., T. Rutherford, and D. Tarr (2008), 'Modeling Services Liberalization: The Case of Tanzania', Policy Research Working Paper 4801, World Bank.

Konan, D.E. and K. Maskus (2006), 'Quantifying the Impact of Services Liberalization in a Developing Country', Journal of Development Economics 1: $142-62$.

Lee, H. and K. Itakura (2013), The Implications of Region-wide FTAs for Japan and Emerging Asia. https://www.aeaweb.org/aea/2014conference/program/ retrieve.php. 
Ludena, C.E., T.W. Hertel, P.V. Preckel, K. Foster, and A. Nin (2007), 'Productivity Growth and Convergence in Crop, Ruminant, and Nonruminant Production: Measurement and Forecasts', Agricultural Economics 37(1): 1-17.

Mukhopadhyay, K. and P.J. Thomassin (2010), Economic and Environmental Impact of Free Trade in East and South East Asia. Dordrecht: Springer.

Narayanan, G.B., A. Aguiar, and R. McDougall (2012), 'Global Trade, Assistance, and Production: The GTAP 8 Data Base'. http://www.gtap.agecon.purdue.edu/ databases/v8/v8_doco.asp (accessed September 2015).

Robinson, S., Z. Wang, and W. Martin (2002), 'Capturing the Implications of Services Trade Liberalization', Economic Systems Research 14(1): 3-33.

Rutherford, T., D. Tarr, and O. Shepotylo (2005), The Impact on Russia of WTO Accession and the Doha Agenda: The Importance of Liberalization of Barriers against Foreign Direct Investment in Services for Growth and Poverty Reduction. Washington, DC: World Bank.

Sato, H. (2014), How Can ASEAN and Japan Mutually Benefit from ASEAN Economic Integration? Bangkok: ILO.

Tongzon, J.and I.Cheong(2016), 'TheImpact of ASEAN-Korea FreeTradeinServices (AKTIS) Agreement: Indonesia and Other ASEAN Countries' Perspective', Bulletin of Indonesian Economic Studies, DOI: 10.1080/00074918.2015.1129048.

United Nations (2012), 'Revised Population Database', UN Population Division.

Versetti, A. and A. Heal (2015), 'Japan-ASEAN Economic Partnership: Prospects for 2015 and Beyond', United Nations United Nations Economic and Social Commission for Asia and the Pacific (UNESCAP), Trade Insights, Issue no. 5, February.

Vo, T. and P. Bartlett (2006), 'Ten Years of ASEAN Framework Agreement on Services (AFAS): An Assessment', REPSEF Project No 05/004, Jakarta: ASEAN Secretariat.

Wang, Z., S. Mohan, and D. Rosen (2009), 'Methodology for Estimating Services Trade Barriers'. Rhodium Group and Peterson Institute for International Economics.

Whalley, J. (2003), 'Assessing the Benefits to Developing Countries of Liberalization in Services Trade', World Economy 27: 1223-53.

Yang C. (2009), 'Analysis on the Service Trade between China [People's Republic of China] and ASEAN', International Journal of Economics and Finance 1(1): $221-4$. 


\section{APPENDIX 4A.1 MODEL DESCRIPTION}

The Global Trade Analysis Project (GTAP) model incorporates both demand and supply in its specifications (Hertel 1997). On the demand side, the model uses a Cobb-Douglas aggregate utility function to allocate regional household expenditure among private expenditure, government expenditure and savings along a constant budget share to provide an indicator of welfare for the regional household. Here, a representative household in each region maximizes constant difference of elasticity expenditure (CDE) functions calibrated to an income level and elasticity of demand that vary according to a region's level of development and consumption pattern.

On the supply side, firms combine primary factors and intermediate goods using the Leontief production structure and a constant return-toscale technology to produce final goods in a perfectly competitive environment. The final goods produced are then sold to both private households and government. There are five primary factors of production in the model - capital, land, natural resources, skilled and semi-skilled labor. The GTAP model uses a nested constant elasticity of substitution (CES) function to determine firm demand for primary and intermediate inputs. The GTAP model utilizes the Armington approach to goods and services. With this approach, goods and services are differentiated by region of origin and are imperfect substitutes. Using this method, an optimal combination of imported and domestic goods can be calculated to be used in production. The GTAP model also incorporates two global sectors apart from regional sectors: (i) the global banking sector that facilitates global savings and investments; and (ii) global transportation to account for the difference between free on board (fob) and cost, insurance and freight (cif) values. In addition, domestic support and trade barriers (tariff and nontariff) are measured in ad valorem equivalents. The equilibrium nature of the model is derived from the accounting relationship that makes up the model. For the closure to work, the number of endogenous variables considered has to be equal to the number of equations used. This is a necessary but not a sufficient condition. The choice of exogenous variable will help determine whether the model is in general or partial equilibrium. Finally, in a standard GTAP closure, all markets are in equilibrium, with all firms earning zero profit and regional household on its budget constraint. 
Table 4A.1 GTAP 8 database sectors and sectoral aggregation

\begin{tabular}{|c|c|c|c|c|}
\hline Number & Code & Sector in GTAP & $\begin{array}{l}\text { Name of the aggregated } \\
\text { sector }\end{array}$ & Number \\
\hline 1 & PDR & Paddy rice & Agriculture & 1 \\
\hline 2 & WHT & Wheat & Agriculture & 1 \\
\hline 3 & GRO & Cereal grains, nec & Agriculture & 1 \\
\hline 4 & V_F & Vegetables, fruit, nuts & Agriculture & 1 \\
\hline 5 & OSD & Oilseeds & Agriculture & 1 \\
\hline 6 & C_B & Sugarcane, sugar beet & Agriculture & 1 \\
\hline 7 & PFB & Plant-based fibers & Agriculture & 1 \\
\hline 8 & OCR & Crops, nec & Agriculture & 1 \\
\hline 9 & CTL & $\begin{array}{l}\text { Bovine cattle, sheep, } \\
\text { and goats, horses }\end{array}$ & $\begin{array}{l}\text { Livestock and livestock } \\
\text { products }\end{array}$ & 2 \\
\hline 10 & OAP & Animal products, nec & $\begin{array}{l}\text { Livestock and livestock } \\
\text { products }\end{array}$ & 2 \\
\hline 11 & RMK & Raw milk & $\begin{array}{l}\text { Livestock and livestock } \\
\text { products }\end{array}$ & 2 \\
\hline 12 & WOL & $\begin{array}{l}\text { Wool, silk-worm } \\
\text { cocoons }\end{array}$ & $\begin{array}{l}\text { Livestock and livestock } \\
\text { products }\end{array}$ & 2 \\
\hline 13 & FRS & Forestry & Forestry & 3 \\
\hline 14 & FSH & Fishing & Fishing & 4 \\
\hline 15 & $\mathrm{COA}$ & Coal & Fuel mineral & 5 \\
\hline 16 & OIL & Oil & Fuel mineral & 5 \\
\hline 17 & GAS & Gas & Fuel mineral & 5 \\
\hline 18 & OMN & Minerals, nec & Fuel mineral & 5 \\
\hline 19 & CMT & Bovine meat products & $\begin{array}{l}\text { Livestock and livestock } \\
\text { products }\end{array}$ & 2 \\
\hline 20 & OMT & Meat products, nec & $\begin{array}{l}\text { Livestock and livestock } \\
\text { products }\end{array}$ & 2 \\
\hline 21 & VOL & $\begin{array}{l}\text { Vegetable oils and } \\
\text { fats }\end{array}$ & Vegetable oils and fats & 6 \\
\hline 22 & MIL & Dairy products & Dairy products & 8 \\
\hline 23 & PCR & Processed rice & Processed rice & 8 \\
\hline 24 & SGR & Sugar & Sugar & 7 \\
\hline 25 & OFD & Food products, nec & $\begin{array}{l}\text { Food products and } \\
\text { beverages }\end{array}$ & 8 \\
\hline 26 & B_T & $\begin{array}{l}\text { Beverages and } \\
\text { tobacco } \\
\text { products }\end{array}$ & $\begin{array}{l}\text { Food products and } \\
\text { beverages }\end{array}$ & 8 \\
\hline 27 & TEX & Textiles & $\begin{array}{l}\text { Textile and wearing } \\
\text { apparel }\end{array}$ & 9 \\
\hline 28 & WAP & Wearing apparel & $\begin{array}{l}\text { Textile and wearing } \\
\text { apparel }\end{array}$ & 9 \\
\hline 29 & LEA & Leather products & Leather products & 10 \\
\hline
\end{tabular}


Table 4A.1 (continued)

\begin{tabular}{|c|c|c|c|c|}
\hline Number & Code & Sector in GTAP & $\begin{array}{l}\text { Name of the aggregated } \\
\text { sector }\end{array}$ & Number \\
\hline 30 & LUM & Wood products & Wood products & 11 \\
\hline 31 & PPP & $\begin{array}{l}\text { Paper products, } \\
\text { publishing }\end{array}$ & $\begin{array}{l}\text { Paper products, } \\
\text { publishing }\end{array}$ & 12 \\
\hline 32 & P_C & $\begin{array}{l}\text { Petroleum, coal } \\
\text { products }\end{array}$ & $\begin{array}{l}\text { Petroleum, coal } \\
\text { products }\end{array}$ & 13 \\
\hline 33 & CRP & $\begin{array}{l}\text { Chemical, rubber, } \\
\text { plastic products }\end{array}$ & $\begin{array}{l}\text { Chemical, rubber, plastic } \\
\text { products }\end{array}$ & 14 \\
\hline 34 & NMM & Mineral products, nec & Mineral products, nec & 15 \\
\hline 35 & I_S & Ferrous metals & $\begin{array}{l}\text { Metal and metal } \\
\text { products }\end{array}$ & 16 \\
\hline 36 & NFM & Metals, nec & $\begin{array}{l}\text { Metal and metal } \\
\text { products }\end{array}$ & 16 \\
\hline 37 & FMP & Metal products & $\begin{array}{l}\text { Metal and metal } \\
\text { products }\end{array}$ & 16 \\
\hline 38 & MVH & $\begin{array}{l}\text { Motor vehicles and } \\
\text { parts }\end{array}$ & $\begin{array}{l}\text { Motor vehicles and } \\
\text { parts }\end{array}$ & 17 \\
\hline 39 & OTN & $\begin{array}{l}\text { Transport equipment, } \\
\text { nec }\end{array}$ & $\begin{array}{l}\text { Transport equipment } \\
\text { nec }\end{array}$ & 18 \\
\hline 40 & ELE & Electronic equipment & Electronic equipment & 19 \\
\hline 41 & OME & $\begin{array}{l}\text { Machinery and } \\
\text { equipment, nec }\end{array}$ & $\begin{array}{l}\text { Machinery and } \\
\text { equipment, nec }\end{array}$ & 20 \\
\hline 42 & $\mathrm{OMF}$ & Manufactures, nec & Manufactures, nec & 21 \\
\hline 43 & ELY & Electricity & $\begin{array}{l}\text { Construction and } \\
\text { utilities }\end{array}$ & 22 \\
\hline 44 & GDT & $\begin{array}{l}\text { Gas manufacture, } \\
\text { distribution }\end{array}$ & $\begin{array}{l}\text { Construction and } \\
\text { utilities }\end{array}$ & 22 \\
\hline 45 & WTR & Water & $\begin{array}{l}\text { Construction and } \\
\text { utilities }\end{array}$ & 22 \\
\hline 46 & CNS & Construction & $\begin{array}{l}\text { Construction and } \\
\text { utilities }\end{array}$ & 22 \\
\hline 47 & TRD & Trade & Trade & 23 \\
\hline 48 & OTP & Transport, nec & Transport, nec & 24 \\
\hline 49 & WTP & Water transport & Water transport & 25 \\
\hline 50 & ATP & Air transport & Air transport & 26 \\
\hline 51 & $\mathrm{CMN}$ & Communication & Communication & 27 \\
\hline 52 & OFI & Financial services, nec & Financial services, nec & 28 \\
\hline 53 & ISR & Insurance & Other private services & 29 \\
\hline 54 & OBS & Business services, nec & Other private services & 29 \\
\hline 55 & ROS & $\begin{array}{l}\text { Recreational and other } \\
\text { services }\end{array}$ & Other private services & 29 \\
\hline
\end{tabular}


Table 4A.1 (continued)

\begin{tabular}{llllc}
\hline Number & Code & Sector in GTAP & $\begin{array}{l}\text { Name of the aggregated } \\
\text { sector }\end{array}$ & Number \\
\hline 56 & OSG & $\begin{array}{l}\text { Public Administration, } \\
\text { Defense, Education, }\end{array}$ & Government Services & 30 \\
& & $\begin{array}{l}\text { Health } \\
\text { Dwellings }\end{array}$ & Government Services & 30 \\
\hline
\end{tabular}

Note: $\quad$ nec $=$ not elsewhere classified.

Source: Original GTAP database is from Narayanan et al. (2012). 


\section{APPENDIX 4A.2 AGGREGATION SCHEME OF REGION AND SECTORS}

\section{Table 4A.2 Economies and regions in GTAP 8 database and regional aggregation}

\begin{tabular}{|c|c|c|}
\hline Number & Original region & Aggregated region \\
\hline 1 & Australia & Australia \& New Zealand \\
\hline 2 & New Zealand & Australia \& New Zealand \\
\hline 3 & Rest of Oceania & Rest of World \\
\hline 4 & People's Republic of China & People's Republic of China \\
\hline 5 & Hong Kong, China & Rest of World \\
\hline 6 & Japan & Japan \\
\hline 7 & Republic of Korea & Republic of Korea \\
\hline 8 & Mongolia & Rest of World \\
\hline 9 & Taipei,China & Rest of World \\
\hline 10 & Rest of East Asia & Rest of World \\
\hline 11 & Cambodia & Rest of ASEAN \\
\hline 12 & Indonesia & Indonesia \\
\hline 13 & Lao People's Democratic Republic & Rest of ASEAN \\
\hline 14 & Malaysia & Malaysia \\
\hline 15 & Philippines & Philippines \\
\hline 16 & Singapore & Singapore \\
\hline 17 & Thailand & Thailand \\
\hline 18 & Viet Nam & Viet Nam \\
\hline 19 & Rest of Southeast Asia & Rest of ASEAN \\
\hline 20 & Bangladesh & Rest of World \\
\hline 21 & India & India \\
\hline 22 & Nepal & Rest of World \\
\hline 23 & Pakistan & Rest of World \\
\hline 24 & Sri Lanka & Rest of World \\
\hline 25 & Rest of South Asia & Rest of World \\
\hline 26 & Canada & Rest of OECD \\
\hline 27 & United States of America & Rest of OECD \\
\hline 28 & Mexico & Rest of OECD \\
\hline 29 & Rest of North America & Rest of World \\
\hline 30 & Argentina & Rest of World \\
\hline 31 & Plurinational Republic of Bolivia & Rest of World \\
\hline 32 & Brazil & Rest of World \\
\hline 33 & Chile & Rest of OECD \\
\hline 34 & Colombia & Rest of World \\
\hline 35 & Ecuador & Rest of World \\
\hline 36 & Paraguay & Rest of World \\
\hline 37 & Peru & Rest of World \\
\hline 38 & Uruguay & Rest of World \\
\hline
\end{tabular}


Table 4A.2 (continued)

\begin{tabular}{|c|c|c|}
\hline Number & Original region & Aggregated region \\
\hline 39 & Venezuela & Rest of World \\
\hline 40 & Rest of South America & Rest of World \\
\hline 41 & Costa Rica & Rest of World \\
\hline 42 & Guatemala & Rest of World \\
\hline 43 & Honduras & Rest of World \\
\hline 44 & Nicaragua & Rest of World \\
\hline 45 & Panama & Rest of World \\
\hline 46 & El Salvador & Rest of World \\
\hline 47 & Rest of Central America & Rest of World \\
\hline 48 & Caribbean & Rest of World \\
\hline 49 & Austria & Rest of OECD \\
\hline 50 & Belgium & Rest of OECD \\
\hline 51 & Cyprus & Rest of World \\
\hline 52 & Czech Republic & Rest of OECD \\
\hline 53 & Denmark & Rest of OECD \\
\hline 54 & Estonia & Rest of OECD \\
\hline 55 & Finland & Rest of OECD \\
\hline 56 & France & Rest of OECD \\
\hline 57 & Germany & Rest of OECD \\
\hline 58 & Greece & Rest of OECD \\
\hline 59 & Hungary & Rest of OECD \\
\hline 60 & Ireland & Rest of OECD \\
\hline 61 & Italy & Rest of OECD \\
\hline 62 & Latvia & Rest of World \\
\hline 63 & Lithuania & Rest of World \\
\hline 64 & Luxembourg & Rest of OECD \\
\hline 65 & Malta & Rest of World \\
\hline 66 & Netherlands & Rest of OECD \\
\hline 67 & Poland & Rest of OECD \\
\hline 68 & Portugal & Rest of OECD \\
\hline 69 & Slovakia & Rest of OECD \\
\hline 70 & Slovenia & Rest of OECD \\
\hline 71 & Spain & Rest of OECD \\
\hline 72 & Sweden & Rest of OECD \\
\hline 73 & United Kingdom & Rest of OECD \\
\hline 74 & Switzerland & Rest of OECD \\
\hline 75 & Norway & Rest of OECD \\
\hline 76 & Rest of EFTA & Rest of World \\
\hline 77 & Albania & Rest of World \\
\hline 78 & Bulgaria & Rest of World \\
\hline 79 & Belarus & Rest of World \\
\hline 80 & Croatia & Rest of World \\
\hline
\end{tabular}


Table 4A.2 (continued)

\begin{tabular}{|c|c|c|}
\hline Number & Original region & Aggregated region \\
\hline 81 & Romania & Rest of World \\
\hline 82 & Russian Federation & Rest of World \\
\hline 83 & Ukraine & Rest of World \\
\hline 84 & Rest of Eastern Europe & Rest of World \\
\hline 85 & Rest of Europe & Rest of World \\
\hline 86 & Kazakhstan & Rest of World \\
\hline 87 & Kyrgyz Republic & Rest of World \\
\hline 88 & Rest of Former Soviet Union & Rest of World \\
\hline 89 & Armenia & Rest of World \\
\hline 90 & Azerbaijan & Rest of World \\
\hline 91 & Georgia & Rest of World \\
\hline 92 & Bahrain & Rest of World \\
\hline 93 & Islamic Republic of Iran & Rest of World \\
\hline 94 & Israel & Rest of World \\
\hline 95 & Kuwait & Rest of World \\
\hline 96 & Oman & Rest of World \\
\hline 97 & Qatar & Rest of World \\
\hline 98 & Saudi Arabia & Rest of World \\
\hline 99 & Turkey & Rest of OECD \\
\hline 100 & United Arab Emirates & Rest of World \\
\hline 101 & Rest of Western Asia & Rest of World \\
\hline 102 & Egypt & Rest of World \\
\hline 103 & Morocco & Rest of World \\
\hline 104 & Tunisia & Rest of World \\
\hline 105 & Rest of North Africa & Rest of World \\
\hline 106 & Cameroon & Rest of World \\
\hline 107 & Côte d'Ivoire & Rest of World \\
\hline 108 & Ghana & Rest of World \\
\hline 109 & Nigeria & Rest of World \\
\hline 110 & Senegal & Rest of World \\
\hline 111 & Rest of Western Africa & Rest of World \\
\hline 112 & Central Africa & Rest of World \\
\hline 113 & South Central Africa & Rest of World \\
\hline 114 & Ethiopia & Rest of World \\
\hline 115 & Kenya & Rest of World \\
\hline 116 & Madagascar & Rest of World \\
\hline 117 & Malawi & Rest of World \\
\hline 118 & Mauritius & Rest of World \\
\hline 119 & Mozambique & Rest of World \\
\hline 120 & United Republic of Tanzania & Rest of World \\
\hline 121 & Uganda & Rest of World \\
\hline 122 & Zambia & Rest of World \\
\hline
\end{tabular}


Table 4A.2 (continued)

\begin{tabular}{lll}
\hline Number & Original region & Aggregated region \\
\hline 123 & Zimbabwe & Rest of World \\
124 & Rest of Eastern Africa & Rest of World \\
125 & Botswana & Rest of World \\
126 & Namibia & Rest of World \\
127 & South Africa & Rest of World \\
128 & Rest of South African Customs & Rest of World \\
& $\quad$ Union & \\
129 & Rest of World & Rest of World \\
\hline
\end{tabular}

Note: $\quad$ ASEAN $=$ Association of Southeast Asian Nations, OECD $=$ Organisation for Economic Co-operation and Development, EFTA = European Free Trade Association.

Source: Original GTAP database is from Narayanan et al. (2012) 


\section{APPENDIX 4A.3 IMPACT OF SERVICE TRADE LIBERALIZATION TO LABOR SECTOR}

Table 4A.3 Scenario 1: ASEAN-tariff reductions of selected service sectors within ASEAN (\%)

\begin{tabular}{lcc}
\hline & Semi-skilled Labor & Skilled Labor \\
\hline 1. Malaysia & 0.173 & 0.2348 \\
2. Indonesia & 0.0963 & 0.0822 \\
3. Thailand & 0.4395 & 0.4117 \\
4. Viet Nam & 0.2065 & 0.1813 \\
5. Singapore & 0.2928 & 0.4261 \\
6. Philippines & 0.0978 & 0.1332 \\
7. Rest of ASEAN & 0.2089 & 0.4318 \\
\hline
\end{tabular}

Table 4A.4 Scenario 2: ASEAN+3-tariff reductions of selected service sectors within ASEAN and between ASEAN and the PRCJapan-Republic of Korea (\%)

\begin{tabular}{lcc}
\hline & Semi-skilled Labor & Skilled Labor \\
\hline 1. Malaysia & 0.3184 & 0.3421 \\
2. Indonesia & 0.2044 & 0.1598 \\
3. Thailand & 0.935 & 0.7803 \\
4. Viet Nam & 0.3742 & 0.1828 \\
5. Singapore & 0.309 & 0.9171 \\
6. Philippines & 0.1495 & 0.1586 \\
7. Rest of ASEAN & 0.2246 & 0.3869 \\
\hline
\end{tabular}

Table 4A.5 Scenario 3: ASEAN+Republic of Korea-tariff reductions of selected service sectors between ASEAN and the Republic of Korea (\%)

\begin{tabular}{lcc}
\hline & Semi-skilled Labor & Skilled Labor \\
\hline 1. Malaysia & 0.209 & 0.521 \\
2. Indonesia & 0.410 & 0.611 \\
3. Thailand & 0.382 & 0.742 \\
4. Viet Nam & 0.109 & 0.420 \\
5. Singapore & 0.311 & 0.829 \\
6. Philippines & 0.519 & 0.721 \\
7. Rest of ASEAN & 0.360 & 0.431 \\
\hline
\end{tabular}


Table 4A.6 Scenario 4: ASEAN + Japan-tariff reductions of selected service sectors between ASEAN and Japan (\%)

\begin{tabular}{lcc}
\hline & Semi-skilled Labor & Skilled Labor \\
\hline 1. Malaysia & 0.212 & 0.712 \\
2. Indonesia & 0.344 & 0.672 \\
3. Thailand & 0.609 & 0.621 \\
4. Viet Nam & 0.441 & 0.782 \\
5. Singapore & 0.311 & 0.733 \\
6. Philippines & 0.572 & 0.809 \\
7. Rest of ASEAN & 0.107 & 0.209 \\
\hline
\end{tabular}

Table 4A.7 Scenario 5: ASEAN + the People's Republic of China (PRC) - tariff reductions of selected service sectors between $A S E A N$ and the PRC (\%)

\begin{tabular}{lcc}
\hline & Semi-skilled Labor & Skilled Labor \\
\hline 1. Malaysia & 0.176 & 0.651 \\
2. Indonesia & 0.672 & 0.812 \\
3. Thailand & 0.565 & 0.721 \\
4. Viet Nam & 0.334 & 0.503 \\
5. Singapore & 0.140 & 0.973 \\
6. Philippines & 0.292 & 0.422 \\
7. Rest of ASEAN & 0.120 & 0.186 \\
\hline
\end{tabular}

Table 4A.8 Scenario 6: ASEAN+India-tariff reductions of selected service sectors between $A S E A N$ and India (\%)

\begin{tabular}{lcc}
\hline & Semi-skilled Labor & Skilled Labor \\
\hline 1. Malaysia & 0.21 & 0.2421 \\
2. Indonesia & 0.344 & 0.253 \\
3. Thailand & 0.435 & 0.5803 \\
4. Viet Nam & 0.1742 & 0.2828 \\
5. Singapore & 0.209 & 0.7243 \\
6. Philippines & 0.2495 & 0.2586 \\
7. Rest of ASEAN & 0.3246 & 0.1869 \\
\hline
\end{tabular}

